\title{
DAYA PRAGMATIK (PRAGMATIK FORCE) PADA PERBANDINGAN ANTONIM BAHASA JAWA DAN BAHASA INDONESIA SERTA KORELASI BUDAYA MASYARAKAT PENUTURNYA
}

\author{
Paramita Ida Safitri ${ }^{1}$, Rosika Herwin Puspitasari ${ }^{2}$ \\ S2 Pendidikan Bahasa Indonesia Universitas Sebelas Maret \\ ${ }^{1}$ paramita7717@gmail.com; ${ }^{2}$ rosikaherwin.puspitasari@yahoo.co.id
}

\begin{abstract}
The meaning of antonyms are simply the words of opposites, antonyms are divided into four kinds namely; (a) absolute, (b) gradation, (c) hierarchical, (d) reciprocal. Antonyms comparative study on Javanese and Indonesian language through study aims to determine the pragmatic force sequence patterns found on speakers of Javanese and Indonesian, to appraise the values contained in the philosophy of speech acts activities, among speakers of Javanese and Indonesian. The data used in this study apart from information obtained from the book of antonyms collection contained in Javanese and Indonesian were also correlated in the application of the usual conversation by speakers of Javanese and Indonesian. The method used in this research through a comparative study done by comparing the antonym that is customarily used by speakers of Javanese and Indonesian speakers. The result of this study showed that the antonyms contained in Javanese and Indonesian language have different sequence patterns, this is due to the differences in cultural bacground contained in the community of Javanese and Indonesian speaker.
\end{abstract}

Keywords: pragmatic force, comparison, antonyms Javanese, Indonesian antonyms, cultural speech community.

\section{PENDAHULUAN}

Bahasa merupakan alat komunikasi yang digunakan oleh manusia dalam kehidupan sehari-hari. Dengan menggunakan bahasa maka manusia dapat menjalin hubungan dengan manusia lain dengan baik dalam melakukan proses interaksi sosial. Dalam bahasa terdapat istilah lawan kata atau biasa disebut antonim. Antonim merupakan struktur semantik yang menekankan hubungan pertentangan makna. Pada dasarnya setiap bahasa memiliki antonim, hanya saja ungkapan kata serta budaya masyarakat penuturnya yang menjadikannya berbeda. Misalnya dalam kajian ini dibandingkan antonim bahasa indonesia dan bahasa jawa. Walaupun pulau Jawa terdapat dalam negara Indonesia, namun pada kenyataannya terdapat perbedaan yang cukup berarti pada pola tutur penutur bahasa Jawa dan penutur bahasa Indonesia, hal ini dikarenakan masyarakat Indonesia memiliki keragaman bahasa serta budaya yang beragam. 
Negara Indonesia merupakan salah satu negara yang kaya akan keanekaragaman bahasa dan budaya, tidak jarang keberagaman ini menjadikan masing-masing masyarakat pemilik budaya berlomba-lomba menonjolkan keunikan budayannya melalui kegiatan tindak tutur, dalam kegiatan tindak tutur ini dapat pula terjadi peristiwa perkawinan antara budaya dan bahasa yang melahirkan suatu filosofi tersendiri yang sangat menarik untuk dikaji. Keunikan ini juga yang menjadi faktor utama penulis untuk melakukan penelitian terhadap bahasa, karena setiap bahasa pada dasarnya memiliki kekhasan tersendiri yang sangat menarik untuk dikaji.

Dalam hal ini penulis menganalisis perbandingan bahasa Jawa dan bahasa Indonesia ditinjau dari segi antonimnya dengan kajian daya pragmatik (pragmatik force). Apa saja keunikan yang terdapat dalam perbandingan antonim kedua bahasa tersebut? Adakah perbedaan dan persamaan pola urutannya? Jika ada, mengapa hal itu terjadi? Pertanyaan tersebut hanya dapat diketahui jawabannya setelah kita melakukan analisis perbandingan antonim yang telah diklasifikasikan dalam ragam antonim terhadap kedua bahasa tersebut.

\section{LANDASAN TEORI}

\section{Daya Pragmatik}

Pragmatik sebagai salah satu bidang kajian bahasa merupakan satu-satunya tataran yang memperhitungkan manusia sebagai pengguna bahasa. Yule (1996:3) mengatakan bahwa pragmatics is the study of how more gets communicated than is said 'pragmatik adalah ilmu yang mempelajari bagaimana mendapatkan apa yang dikomunikasikan'. Pragmatik sebagai salah satu bidang ilmu linguistik, mengkhususkan pengkajian pada hubungan antara bahasa dan konteks tuturan. Berkaitan dengan itu, Mey (dalam Rahardi, 2003:12) mendefinisikan bahwa "pragmatics is the study of the conditions of human language uses as there determined by the context of society", "pragmatik adalah studi mengenai kondisi-kondisi penggunaan bahasa manusia yang ditentukan oleh konteks masyarakat'. Menurut Tarigan (1985: 34) pragmatik 
merupakan telaah umum mengenai bagaimana caranya konteks mempengaruhi cara seseorang menafsirkan kalimat.

Edy Tri Sulistyo (2013:38) menyatakan bahwa, daya pragmatik merupakan makna tersirat dibalik ujaran, yang mampu menggerakkan mitra tuturnya untuk melakukan apa yang dimaksudkan penutur dibalik ujaran yang dituturkannya. Perbedaan antara makna (sense) makna ditentukan secara semantis. Sedangkan daya (force) makna ditentukan secara semantis dan pragmatis. Ikatan antara makna dan daya juga perlu disadari. Daya mencakup makna dan secara semantis, daya sekaligus juga dapat diturunkan dari makna. Menurut Leech (1993: 23) daya pragmatik dibentuk oleh daya ilokusi dan daya retorik secara bersamasama. Daya retorik adalah makna tuturan diihat dari ketaatan penutur pada prinsip-prinsip retorik (misalnya sejauh mana penutur mengatakan yang benar, berbicara dengan sopan, atau bernada ironis). Daya pragmatik berkaitan dengan interpretasi atas tuturan.

Berdasarkan pendapat di atas dapat disimpulkan bahwa yang dimaksud daya pragmatik adalah telaah mengenai kemampuan pemakai bahasa yang menghubungkan serta menyerasikan kalimat dan konteks. Namun dihubungkan dengan situasi atau konteks di luar bahasa tersebut, dan dilihat sebagai sarana interaksi atau komunikasi di dalam masyarakat. Bahasa dan pemakai bahasa tidak teramati secara individual tetapi selalu dihubungkan dengan kegiatan dalam masyarakat. Bahasa tidak hanya dipandang sebagai gejala individual tetapi juga gejala sosial.

\section{Antonim}

Dalam Sarwiji, 2011: 129, (Chaer, 1985: 35) menyatakan bahwa kata antonimi berasal dari bahasa Yunani Kuno onoma yang berarti 'nama' dan anti yang berarti 'melawan'. Dengan demikian, antonim berarti 'nama lain untuk benda yang lain pula'. Secara sematik antonim sering didefinisikan sebagai ungkapan (biasannya berupa kata, tetapi dapat pula berupa frasa atau kalimat) yang maknannya dianggap kebalikan dari ungkapan yang lain. Sementara itu, Kridalaksana (2001: 15) mengungkapkan bahwa antonimi adalah leksem yang berpasangan 
secara antonim. Verhaar (1981: 133) mengatakan: "Antonimi adalah ungkapan (biasanya kata, tetapi dapat juga frase atau kalimat) yang dianggap bermakna kebalikan dari ungkapan alain”.

Berdasakan pendapat para ahli di atas, penulis mengacu pada pendapat Chaer yang mengungkapkan bahwa antonim adalah ungkapan (biasanya berupa kata, tetapi dapat pula dalam bentuk frase atau kalimat) yang maknanya dianggap kebalikan dari makna ungkapan lain. Jadi, hanya dianggap kebalikan bukan mutlak berlawanan. Relasi makna antara dua buah kata yang berantonim bersifat dua arah. Sejalan dengan pernyataan tersebut menegaskan bahwa antonim tidak saja pada tataran kata, tetapi juga pada tataran morfem, frasa, dan kalimat. Kata-kata yang berantonim pada umumnya berupa kata sifat, namun dapat juga berupa kata benda, kata bilangan, kata ganti, kata kerja, dan kata keterangan. Kata-kata tugas seperti dan, untuk, tetapi, dan sebagainya merupakan kata-kata yang tidak berantonim. Dalam Sarwiji, 2011: 129, (Chaer, 1985: 35) disebutkan ragam oposisi makna (antonim) yakni;

\section{Antonim Mutlak}

Antonim mutlak muncul apabila pertentangan antara kata atau bentuk bahasa yang memiliki hubungan antonim tersebut bersifat mutlak. Pengertian antara kedua kata atau bentuk itu terdapat pada batas yang mutlak.

\section{Antonim Gradasi atau Oposisi Kutub}

Kata-kata atau bentuk-bentuk bahasa yang termasuk jenis antonim gradasi mempunyai pertentangan yang tidak mutlak. Ketidakmutlakkkan makna terletak pada adannya tingkatan pada kata-kata. Suatu antonim dapat disebut sebagai antonim gradasi apabila penegatifan suatu kata tidaklah bersinonim dengan kata lain. Pada umumnya kata-kata yang termasuk antonim gradasi adalah kata sifat atau adjektif.

\section{Antonim Relasional}

Antonim relasional adalah jenis antonim yang memperlihatkan kesimetrian dalam makna anggota pasangannya. Biasanya berupa kata kerja dan kata benda. 


\section{Antonim Hierarkial}

Kata-kata yang termasuk dalam antonim hierarkial adalah nama satuan waktu (berat, panjang, isi), nama satuan hitungan dan penanggalan, nama satuan jenjang kepangkatan, dan sebagainya.

\section{Antonim Respirokal}

Antonim respirokal secara fungsional meruapakan antonim yang mempunyai hubungan yang erat berupa hubungan timbal balik.

\section{METODE PENELITIAN}

Metode penelitian yang digunakan dalam menganalisis antonim bahasa Jawa dan bahasa Indonesia menggunakan metode komparasi, yakni membandingkan antara antonim kedua bahasa tersebut. Pengumpulan data antonim bahasa Jawa dan bahasa Indonesia diambil dari kumpulan buku yang digunakan sebagai rujukan yang telah dikorelasikan penerapannya pada penutur bahasa Jawa dan bahasa Indonesia dalam percakapan sehari-hari. Data dikumpulkan dan diklasifikasikan menurut ragam antonim dan dianalisis persamaan dan perbedaan pola urutan antonim dua bahasa tersebut.

\section{PEMBAHASAN}

Berikut adalah klasifikasi analisis antonim bahasa Jawa dan bahasa Indonesia berdasarkan ragam antonim.

\section{1) Antonim Mutlak}

\begin{tabular}{lllllll} 
No. & \multicolumn{2}{l}{ Antonim Bahasa Jawa } & \multicolumn{3}{l}{ Antonim Bahasa Indonesia } \\
\hline 1. & ganjil & $\mathrm{x}$ & genep & ganjil & $\mathrm{x}$ & genap \\
\hline 2. & asli & $\mathrm{x}$ & palsu & asli & $\mathrm{x}$ & palsu \\
\hline 3. & bener & $\mathrm{x}$ & luput & benar & $\mathrm{x}$ & salah \\
\hline 4. & mati & $\mathrm{x}$ & urip & hidup & $\mathrm{x}$ & mati \\
\hline 5 & ngisor & $\mathrm{x}$ & dhuwur & atas & $\mathrm{x}$ & bawah \\
\hline 6. & mlebu & $\mathrm{x}$ & metu & keluar & $\mathrm{x}$ & masuk \\
\hline 7. & halal & $\mathrm{x}$ & haram & halal & $\mathrm{x}$ & haram \\
\hline
\end{tabular}


a) (mati $x$ urip) dan (hidup $x$ mati),

b) (ngisor $x$ dhuwur) dan (atas $x$ bawah)

c) (mlebu $x$ metu) dan (keluar $x$ masuk)

Perbedaan pola urutan pada analisis antonim mutlak tersebut terjadi karena perbedaan pandangan hidup. Pada penutur masyarakat Jawa umumnya berpedoman pada peribahasa alon-alon waton klakon, klemet-klemet waton slamet. Dua kalimat Jawa tersebut menunjukan bahwa pada penutur masyarakat Jawa umumnya melakukan segala sesuatunya dimulai dari nol, dari hal-hal yang kecil, penutur bahasa Jawa cenderung ngati-ati (berhati-hati) dalam memutuskan segala sesuatu, mempertimbangkan secara matang dampak baik dan buruknya.

Pada poin (b) diartikan bahwa pada masyarakat penutur bahasa Jawa cenderung pandai menjunjung tinggi kehormatan nama baik diri dan anggota keluarganya serta memendam dalam-dalam aib atau hal-hal yang buruk, seperti yang terdapat dalam peribahasa Jawa yakni mikul dhuwur mendem jero. Sedangkan pada masyarakat penutur bahasa Indonesia cenderung menginginkan segala sesuatunya dengan cara instan (grusagrusu), hal ini mungkin dikerenakan mayoritas masyarakat penutur bahasa Indonesia adalah masyarakat modern, dimana mayoritas masyarakatnya tidak menyukai hal-hal yang berbau repot (njlimet). Hal ini sesuai dengan ungkapan yang kerap digunakan oleh penutur bahasa Indonesia lebih cepat lebih baik.

Pada poin (c) (mlebu $x \quad$ metu) dan (keluar $x$ masuk) dapat diibaratkan bagaimana masyarakat penutur bahasa Jawa ketika memasuki wilayah keraton menggunakan salam yang begitu santun, dan pada saat keluar pun tidak lalai berpamitan dengan cara yang sangat "ngajeni" priyayi, dengan cara "mundhuk-mundhuk" dan kerapkali terkesan berlebihan. Sedangkan pada masyarakat penutur bahasa Indonesia cenderung seenaknya sendiri, misalnya budaya mengucapkan salam ketika memasuki rumah sudah tidak lagi diuri-uri (tidak lagi menjadi hudaya), pada saat masuk rumah dan mendapati kedua orang tua mereka tidak mengucapkan salam, keluar masuk rumah 
tanpa ada tegur sapa dengan penghuni rumah sudah menjadi budaya yang lumrah pada masyarakat penutur bahasa Indonesia.

\section{2) Antonim Gradasi Atau Oposisi Kutub}

No. Antonim Bahasa Jawa

\begin{tabular}{l|llllll}
\hline 1. & adhem & $\mathrm{x}$ & panas & panas & $\mathrm{x}$ & dingin \\
\hline 2. & angel & $\mathrm{x}$ & gampang & mudah & $\mathrm{x}$ & sulit \\
\hline 3. & adoh & $\mathrm{x}$ & cedhak & jauh & $\mathrm{x}$ & dekat \\
\hline 4. & mentah & $\mathrm{x}$ & mateng & mateng & $\mathrm{x}$ & mentah \\
\hline 5. & mlarat & $\mathrm{x}$ & sugih & kaya & $\mathrm{x}$ & miskin \\
\hline 6. & abot & $\mathrm{x}$ & entheng & berat & $\mathrm{x}$ & ringan \\
\hline 7. & kuwat & $\mathrm{x}$ & ringkih & kuat & $\mathrm{x}$ & rapuh \\
\hline
\end{tabular}

a) (adhem $x$ panas) dan (panas $x$ dingin)

b) (angel $x$ gampang) dan (mudah $x$ sulit)

c) (mentah $x$ mateng) dan (mateng $x$ mentah)

d) (mlarat $x$ sugih) dan (kaya $x$ miskin)

Pada poin (a) dan (b) dapat diibaratkan pernyataan perlawanan 'panas dan dingin' adalah kepala sedangkan 'sulit dan gampang' adalah suatu persoalan atau permasalahan. Pada umumnya masyarakat Jawa ketika mendapat suatu permasalah mereka menyelesaikannya dengan legowo, nrimo ing pandum, nrimo kanthi ikhlash sekabehe pangujining Gusti karo awak dewe (menerima dengan ikhlash terhadap semua yang diberikan Allah terhadap diri kita). Tidak ketinggalan moto hidup yang sudah tenar dikalangan masyarakat yakni; 'pak lurah nggowo bedil, gusti Allah Maha adil', kutipan ini menandakan bahwa budaya pada masyarakat penutur bahasa Jawa dalam menyelesaikan segala permasalah dengan kepala serta hati yang dingin, sehingga segala hal yang dirasa sulit dapat terselesaikan dengan mudah. Sedangkan pada masyarakat penutur bahasa Indonesia ketika dihadapkan pada suatu problematika cenderung mengedepankan emosi.

Penjelasan makna pada poin (b) misalnya saja pada masyarakat penutur bahasa Indonesia yang mayoritas masyarakatnya bermukim di ibukota sadar dan paham benar kebiasaan membuang sampah pada tempatnya dapat meminimalisir terjadinya bencana banjir, namun kebanyakan mereka mengabaikan hal tersebut. Mereka senantiasa 
mengabaikan kebiasaan baik yang sebenarnya mudah menjadi bencana yang menyulitkan mereka sendiri.

Pada poin (c) (mentah $x$ mateng) dan (mateng $x$ mentah) dapat juga kedua antonim dalam dua bahasa tersebut diibaratkan sebagai kepribadian dua masyarakat penutur bahasa tersebut, pada masyarakat penutur bahasa Jawa diajarkan unggahungguh bahasa sejak kecil sehingga pada saat mereka berkomunikasi dengan orang yang lebih tua, akan menyesuaikan pemakaian bahasa yang digunakan, secara tidak langsung hal ini lambat-laun dapat menjadi media yang efektif dalam penanaman budi pekerti, sedangkan pada masyarakat penutur bahasa Indonesia tidak terdapat tingkatan bahasa yang berarti seperti yang terdapat dalam bahasa Jawa, sehingga pada masyarakat penutur bahasa Indonesia walaupun usiannya sudah matang, akan tetapi penanaman nilai-nilai budi pekerti mereka terhadap sesama cenderung mentah.

Pada poin (d) (mlarat $x$ sugih) dan (kaya $x$ miskin) kata antonim pada dua bahasa ini dapat diibaratkan dengan keadaan ekonomi antara masyarakat penutur Jawa dan masyarakat penutur Indonesia. Pada masyarakat Jawa yang mata pencaharian hidupnya hampir seragam yakni sebagai petani hidupnya sebatas berkecukupan, kelas sosial tidak begitu nampak antara satu sama lain, sedangkan pada masyarakat perkotaan, yang masing-masing satu sama lainnya memiliki pekerjaan dan penghasilan yang beragam, perbandingan kelas sosial sangat jelas terlihat antara si kaya dan si miskin.

\section{Antonim Relasional}

\begin{tabular}{llllllll} 
No. & \multicolumn{2}{l}{ Antonim Bahasa Jawa } & \multicolumn{3}{l}{ Antonim Bahasa Indonesia } \\
\hline 1. & babu & $\mathrm{x}$ & bandara & majikan & $\mathrm{x}$ & pembantu \\
\hline 2. & kuli & $\mathrm{x}$ & mandor & mandor & $\mathrm{x}$ & kuli \\
\hline 3. & bopo & $\mathrm{x}$ & biyung & ayah & $\mathrm{x}$ & ibu \\
\hline 4. & kanca & $\mathrm{x}$ & satru & teman & $\mathrm{x}$ & musuh \\
\hline 5. & guru & $\mathrm{x}$ & murid & guru & $\mathrm{x}$ & murid \\
\hline 6. & lanang & $\mathrm{x}$ & wedhok & laki-laki & $\mathrm{x}$ & perempuan \\
\hline 7. & jago & $\mathrm{x}$ & babon & pejantan & $\mathrm{x}$ & betina
\end{tabular}

a) (Babu $x$ bandara) dan (majikan $x$ pembantu)

b) (kuli $x$ mandor) dan (mandor $x$ kuli) 
Pada kedua kata ini dapat diibaratkan kedudukan manusia dimata manusia pada poin (a) dan (b) menandakan bahwa pada masyarakat penutur bahasa Indonesia kedudukan mandor dan majikan begitu diutamakan dan dirajakan terbukti saat ini marak tindak kekerasan yang menganiaya pembantunya bahkan tega sampai membunuhnya, dalam hal ini seorang pembantu seperti tidak ada harganya (tidak dimanusiakan). Dalam masyarakat Jawa hubungan antara golongan priyayi dan bukan priyayi tetap harus saling menghormati, unggah-ungguh bahasa Jawa yang ditanamkan sejak kecil membentuk pribadi mereka untuk saling menghormati sesama.

\section{4) Antonim Hierarkial}

No. Antonim Bahasa Jawa

Antonim Bahasa Indonesia

\begin{tabular}{lllllll}
\hline 1. & ons & $\mathrm{x}$ & gram & ons & $\mathrm{x}$ & gram \\
\hline 2. & kilo gram & $\mathrm{x}$ & kuintal & kilo gram & $\mathrm{x}$ & kuintal \\
\hline 3. & gram & $\mathrm{x}$ & kilo gram & gram & $\mathrm{x}$ & kilo gram \\
\hline 4. & meter & $\mathrm{x}$ & kilo meter & meter & $\mathrm{x}$ & kilo meter \\
\hline 5. & detik & $\mathrm{x}$ & menit & detik & $\mathrm{x}$ & menit \\
\hline 6. & kwintal & $\mathrm{x}$ & ton & kwintal & $\mathrm{x}$ & ton \\
\hline 7. & tamtama & $\mathrm{x}$ & bintara & tamtama & $\mathrm{x}$ & bintara \\
\hline
\end{tabular}

Pada analisis antonim hierarkial tidak ditemukan pola urutan yang tidak seragam. Hal ini karena satuan ukuran merupakan aturan yang pasti dan paten dalam masyarakat penutur bahasa tersebut dan tidak terbatas oleh budaya masyarakat penuturnya.

\section{5) Antonim Resiprokal}

No. Antonim Bahasa Jawa Antonim Bahasa Indonesia

\begin{tabular}{lllllll}
\hline 1. & takon & $\mathrm{x}$ & mangsuli & tanya & $\mathrm{x}$ & Jawab \\
\hline 2. & bukak & $\mathrm{x}$ & tutup & buka & $\mathrm{x}$ & tutup \\
\hline 3. & wiwitan & $\mathrm{x}$ & pungkasan & awalan & $\mathrm{x}$ & akhiran \\
\hline 4. & nggeret & $\mathrm{x}$ & nyurung & tarik & $\mathrm{x}$ & dorong \\
\hline 5. & njaluk & $\mathrm{x}$ & weweh & memberi & $\mathrm{x}$ & menerima \\
\hline 6. & gelang & $\mathrm{x}$ & kalung & gelang & $\mathrm{x}$ & kalung \\
\hline 7. & pintu & $\mathrm{x}$ & jendela & pintu & $\mathrm{x}$ & jendela \\
\hline
\end{tabular}

Pada analisis antonim relasional tidak ditemukan perbedaan pola urutan, hal ini dikarenakan hubungan timbal balik antara masyarakat penutur bahasa Jawa dan 
masyarakat penutur bahasa Indonesia memiliki kesamaan yang tidak terpisahkan oleh batasan budaya dalam masyarakat penutur.

\section{SIMPULAN DAN SARAN}

Berdasarkan analisis antonim bahasa Jawa dan antonim bahasa Indonesia melalui empat ragam, yakni (a) mutlak, (b) gradasi, (c) hierarkial, (d) respirokal. Diperoleh kesimpulan bahwa antara bahasa Jawa dan bahasa Indonesia memiliki pola urutan antonim yang berbeda. Faktor utama penyebab perbedaan pola urutan antara bahasa Jawa dan bahasa Indonesia diatas disebabkan karena perbedaan moto atau falsafah hidup, kelas sosial, lingkungan hidup, adat istiadat, pola pikir, gaya hidup, serta tingkatan bahasa yang terdapat di masing-masing masyarakat penutur bahasa tersebut. Misalnya semboyan alon-alon waton klakon, klemet klemet waton slamet, mikul dhuwur mende jero, pak lurah nggowo bedhil Gusti Allah Maha Adil. Sedangkan pada masyarakat penutur bahasa Indonesia segala sesuatunya cenderung abstrak, dalam artian tidak mengenal pakem yang paten dalam memutus dan melakukan tindakan.

Tidak sedikit pula pola urutan yang seragam, bahkan keseluruhan dari analisis ragam antonim hierarkial dan resiprokal memiliki perurutan antonim yang seragam, hal ini dikarenakan karena satuan ukuran (hierarkial) merupakan satuan ukuran yang paten dalam setiap bahasa dan budaya masyarakat penutur. Hubungan timbal balik (resiprokal) masyarakat penutur Jawa dan bahasa Jawa sama, karena kedua bahasa tersebut masih berada dalam negara yang sama, yakni negara Indonesia. Kedekatan ini tentu sangat menentukan keakraban pola urutan yang seragam pada kedua bahasa ini.

Dari uraian perbedaan dan persamaan kedua bahasa diatas menunjukkan bahwa nilai-nilai budaya yang hidup dalam lingkungan masyarakat sangat mempengaruhi tindak tutur seseorang. Pencerminan budaya dalam bahasa ini sebagai wujud eksplorasi jati diri budaya dalam kegiatan bertutur atau filosofi yang memiliki nilai kehidupan atau pesan moral yang kuat. Semuannya itu merupakan sebuah aturan yang tidak tertulis dan sudah 
menjadi budaya leluhur yang mengakar kuat dalam kegiatan tindak tutur antara kedua bahasa tersebut. Namun ada baiknya kita mulai menanamkan falsasah-falsafah yang positif dalam kegiatan tindak tutur, hal ini sekaligus sebagai penanaman karakter yang diharapkan menjadi budaya baik yang kelak mendarah daging pada generasi mendatang.

\section{REFERENSI}

Chaniago, Nur Arifin, dkk.. 2000. Kamus Sinonim-Antonim Bahasa Indonesia. Bandung: Pustaka Setia.

Cummings, Louise. 1999. Pragmatics, A Mutidicplinary Perspective. New York: Oxford University Press. Terjemahan. Ibrahim, Abdul Syukur (editor). 2007. Pragmatik: Sebuah Prespektif Multidispliner. Yogyakarta: Pustaka Pelajar.

Kridalaksana, Harimurti. 2001. Kamus Linguistik. Jakarta: Gramedia Pustaka Utama.

Leech, Geoffrey. 1993. Prinsip-Prinsip Pragmatik. Diterjemahkan oleh M. D. D. Oka. Jakarta: Universitas Indonesia

Leech, Geofrey. 1993. Prinsip-prinsip Pragmatik. Jakarta: Universitas Indonesia.

Rahardi, Kunjana. 2003. Berkenalan dengan Ilmu Bahasa Pragmatik. Malang: Dioma

Raharjo, Sugeng Haryo. 2008. Kawruh Basa Jawa Pepak. Semarang: Widya Karya.

Sarwiji Suwandi. 2011. Semantik Pengantar Kajian Makna. Yogyakarta: Media Perkasa.

Sulistyo, Edy Tri. 2013. Pragmatik Suatu Kajian Awal. Surakarta: UNS Press.

Tarigan, Henry Guntur. 1986. Pragmatik. Bandung : Angkasa.

Verhaar, J. W. M. 1981. Pengantar Linguistik, jilid I, Yogyakarta: Gadjah Mada University Press.

Yule, G. (1996). Pragmatik. Yogyakarta: Pustaka Pelajar. 